\title{
PROPOSAL FOR SOCIAL INDICATORS TO IMPROVE MUNICIPAL SOLID WASTE MANAGEMENT: A PERUVIAN CASE STUDY
}

\author{
LUIS IZQUIERDO-HORNA, MIKER DAMAZO \& DEYVIS YANAYACO \\ Centro de Investigación de Riesgo, Resiliencia y Cambio Climático, Universidad Tecnológica del Perú, Peru
}

\begin{abstract}
The accumulation of waste in Peru has become a problem that affects the entire population and has generated the need to understand how and why this situation has developed. This situation can be described and understood through an examination of the most relevant social indicators of a very specific community. Consequently, it is necessary to understand the link between the situational reality of solid waste accumulation and the social indicators that are relevant to this process. Therefore, the main objective of this research is to contribute to the improvement of municipal solid waste management plans, specifically solid waste collection tasks. To this end, a methodological tool that focuses on the study of social indicators (e.g., age, education level, and financial income, among others) is proposed to identify the sectors most prone to solid waste accumulation. This study proposes a set of indicators that describe the economic, social, and environmental conditions of the location inhabitants and answers the questions initially posed. The district chosen for this case study is Puente Piedra. This research resulted in a set of social indicators divided into sociodemographic, socioeconomic, and sociocultural categories that can be used to forecast future tasks in sectors prone to solid waste accumulation.
\end{abstract}

Keywords: solid waste, social indicators, waste management, Peru.

\section{INTRODUCTION}

Solid waste generation has become a global problem because the planet has experienced alarming levels of production [1]. According to Kaza et al. [2], the world generated 2.01 billion tons of municipal solid waste in 2016 and this number is expected to increase to 3.40 billion tons by 2050 . Consequently, it is important to manage it efficiently, as well as raise awareness among populations to control the problem that is becoming more acute daily. The elimination of solid waste has undoubtedly become a problem that must be treated with the utmost urgency [3].

On the other hand, factors such as continuous economic growth, urbanization, and industrialization, hinder the correct management of solid waste and create a problem for the authorities with responsibility for executing it efficiently [4]. One of the major sources of environmental pollution is domestic solid waste, especially in developing countries, where only $4 \%$ of the waste generated is recycled [2]. Therefore, efficient and modern solutions are being sought in different regions of the world to minimize the production of solid waste; however, the efficacy and success achieved have been uneven and limited [2].

Against this background, this research focuses on studying the process of solid waste generation/accumulation, considering solid waste as any substance or product in a solid or semi-solid state that when it has fulfilled its function or been used and/or served an activity, then is subsequently discarded. The mismanagement of solid waste can create a risk to health and the environment [5], [6]. On the other hand, the management process is divided into hazardous and non-hazardous waste and classified as municipal and non-municipal waste accordingly [7]. The main actors in solid waste policy are the competent authorities, companies, and the population, the latter being the most decisive [8]. 
For this reason, the National Environmental Action Program and the National Environmental Action Plan in Peru have agreed on a priority objective: the comprehensive management of solid waste at the national level. Established goals must be met by 2021, including environmental education about responsible consumption [9]. From this perspective, the Ministry of Environment (MINAM) has identified 28 critical points in 43 districts of Lima. In addition, the Environmental Assessment and Inspection Agency (OEFA) has determined 148 critical points of waste generation (also in Lima), which add up to a total of 8,670 tons of waste per day [10]. However, of the total national waste generated, only $43.5 \%$ is deposited in sanitary landfills and only $55.4 \%$ is deposited correctly or safely [11]. According to Alata [12], the Metropolitan Municipality of Lima registered the generation of more than three million tons of garbage in 2017, which is equivalent to more than 8,970 tons per day. This is an uncomfortable situation for citizens as evidenced by a survey conducted in Lima. The survey results reflected citizens' dissatisfaction with the waste collection service (32.6\%) and the lack of an effective and efficient recycling system (18.9\%) [13].

At an international level, the situation is not very different from that in Peru. A series of projects are being planned and implemented to improve solid waste management. For example, in Colombia, a methodological proposal was developed to determine how much waste of residential origin is generated in developing countries. The results obtained were acceptable for medium-sized cities. The research team conducted prior visits and home surveys which led to a fluid and organized collaboration with the community itself [14]. In Iran on the other hand, the same strategy was applied to 1,782 households to determine the factors associated with domestic solid waste generation, and information was collected through a questionnaire that evaluated sociodemographic factors (e.g., age, marital status, gender, etc.) [15]. Likewise, in Canada, Kannangara et al. [16] conducted research to develop a predictive model based on demographic and socioeconomic indicators. This model was created through a residential mapping exercise in 220 municipalities. They analyzed the data collected detailing the generation of annual residential waste and obtained successful results with a good predictive percentage (72\%).

In the same way, Torres et al. [17] developed a comprehensive management model in Mexico that addressed the problem of solid waste accumulation in public places. The study highlighted the importance of people as fundamental change agents. Similarly, in the Netherlands, an estimate of the amount of solid food waste was made through a survey of 763 citizens using a cell phone application and classification techniques of household solid waste in 130 households [18]. A similar project was conducted in Dehradun, India, where the quantity and quality of household waste were studied in terms of socioeconomic groups and family size [19]. In addition, a study was conducted in Cape Haitian, Republic of Haiti, through a survey of socioeconomic groups and waste generation [20].

An important feature of the studies shown is that, despite their variety, the methods applied in different countries have in many cases involved creative or traditional strategies, such as surveys. In this sense, this research hopes to establish a tool to develop knowledge about the accumulation of solid waste and to elucidate the social, economic, and cultural characteristics that influence this process to improve citizens' living conditions.

This research developed a set of social indicators that identify key spots of solid waste generation in urban areas. Studies conducted from this perspective can be used to georeference the relationship between selected social indicators and solid waste generation. This article is divided into five sections. The first section focuses on describing a global vision of the subject as an introduction. The section that follows describes the methodology and important characteristics of the case study (Puente Piedra district). Section 3 describes the 
main results obtained. Section 4 discusses the most relevant results and finally, the Section 5 presents a conclusion.

\section{METHODOLOGY}

In this section, a description of the methodology, the case study, and the information sources used for this research are presented. The study focuses on an urban area of Lima, in Puente Piedra district. The methodological framework is presented in Fig. 1 and explained in the following paragraphs. The first part details the information collection process and the selection of the case study, using information from work conducted by the Ministry of Environment of Peru (MINAM) and the National Institute of Statistics and Informatics of Peru (INEI). The second part identifies the social indicators used based on the characteristics of the study area and relevant prior information; and finally, an analysis was conducted and selected indicators proposed.

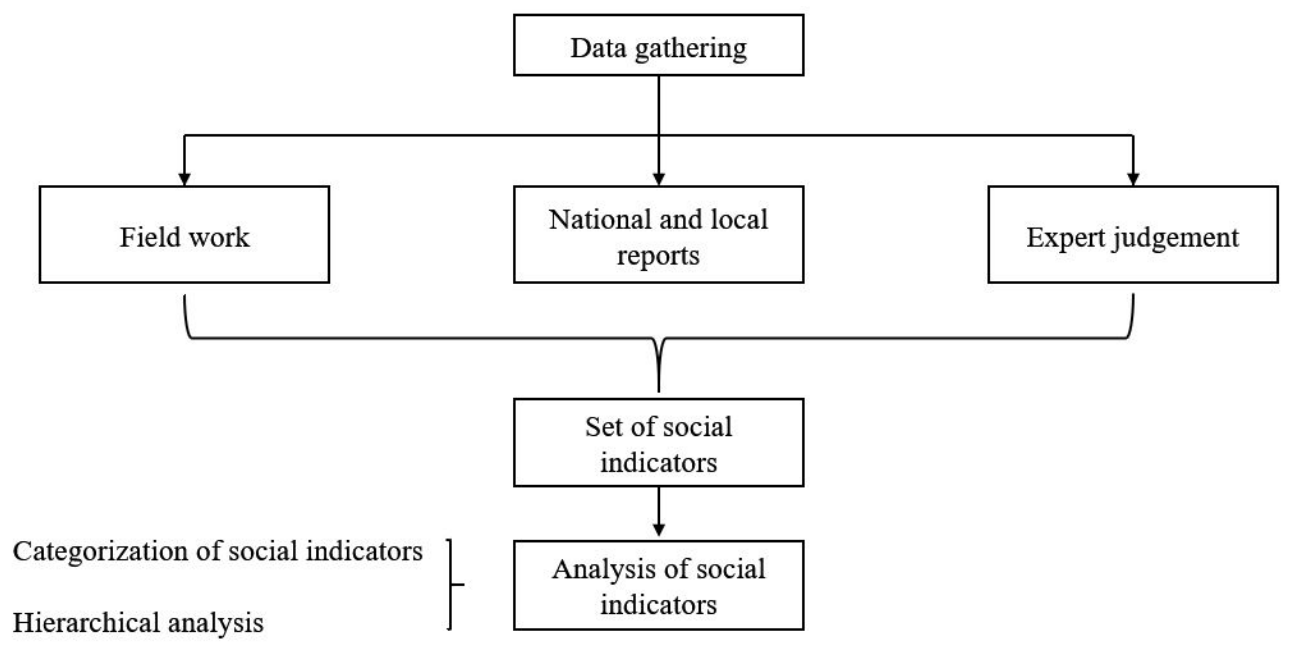

Figure 1: Methodological framework.

\subsection{Description of the case study}

Puente Piedra is located north of Lima Province and is a district with a total area of $72.81 \mathrm{~km}^{2}$ and a population of 329,675 inhabitants [21]. It was chosen not only for its accessibility but also because it is one of the most contaminated districts in Peru [22]. Given the district's land area, we decided to focus on two sectors: "Santa Juana de Copacabana" and "Los Frutales del Norte I" Associations. The location and spatial features of the chosen sectors are presented in Fig. 2.

\subsection{Identification of social indicators}

According to Acuña and Valera [23], one community's social indicators do not necessarily explain the behavior of wider society; therefore, to have greater control and minimize errors, we aimed to identify social indicators specific to the case study location to identify the 


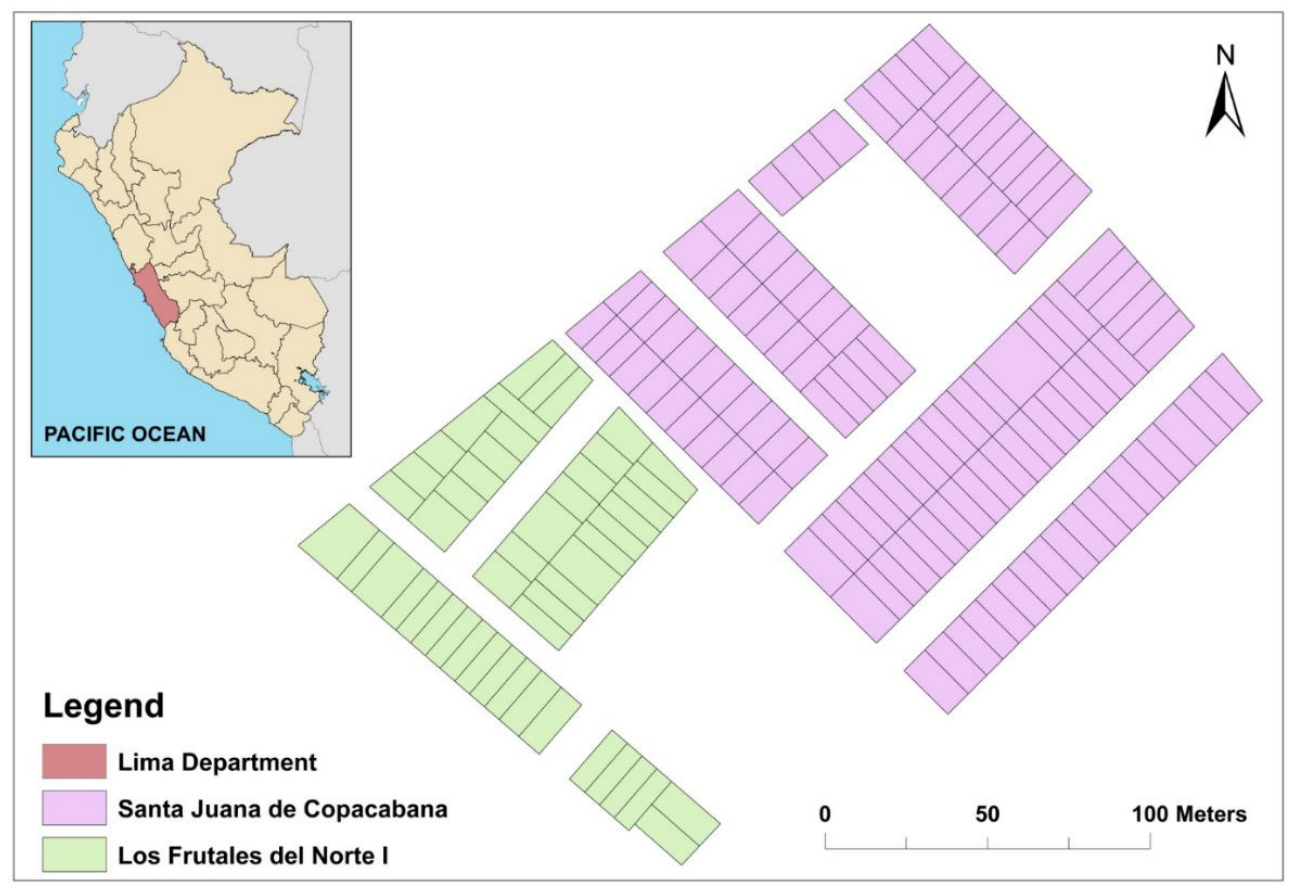

Figure 2: Case Study: Santa Juana de Copacabana and Frutales del Norte I.

average behavior of residents of the study area. For this reason, it was necessary to define what to measure and how to measure it. This project analyzed the most relevant social characteristics influencing the solid waste accumulation process. Therefore, we validated the features of each social indicator to determine its relevance and how representative it was of the topic being studied [24], [25].

We also needed to analyze demographic data and collect information samples to design a survey that covered all the study indicators [19]. For this project, the residents of the study area were interviewed and this information was used to identify the relevant social indicators. This selection process involved establishing communication strategies with the residents to obtain their greatest possible collaboration including awareness workshops, prior visits, and interviews. Another important thing to consider was that each indicator needed linking to both the locality and the dwellings in an environmental context, and the intrinsic characteristics of the physical environment [26].

Social indicators were selected using an existing bibliography and expert judgment. The selection process involved interviews with the residents of both locations, to identify correlations between existing living conditions and the generation of infectious foci. A total of 176 residents were interviewed. Therefore, the assessment process and results obtained in this study are only applicable to a certain time and space; however, the methodology is reproducible at all levels of scale. Finally, the selected social indicators were grouped into three categories for clarity: sociodemographic, socioeconomic, and sociocultural factors. Table 1 presents the set of social indicators proposed for subsequent application in the study area, to make it possible to assess the correlation between the social profile obtained and the locations of solid waste accumulation. 
Table 1: Classification of indicators according to validity and representation.

\begin{tabular}{ll}
\hline Categories & Social indicators \\
\hline \multirow{3}{*}{ Sociodemographic conditions } & Age \\
\cline { 2 - 2 } & Education level \\
\cline { 2 - 2 } Sopulation density \\
\cline { 2 - 2 } Socioeconomic conditions & Land use \\
\cline { 2 - 2 } Sociocultural conditions & Existence of ambulatory trading \\
\hline \multirow{3}{*}{ Average monthly income } \\
\hline
\end{tabular}

\subsection{Analysis of social indicators}

This section explains the procedure involved in applying the social indicators previously selected for identifying possible sectors of solid waste accumulation. For this, the study carried out by Thomas Bohorquez [27] was taken as a reference, since it used a mixture of analysis and data processing tools to improve city planning. The result of this adaptation is shown in Table 2. The sociodemographic, socioeconomic, and sociocultural profile of the study area was expected to be the final product. Multivariate analysis can be conducted to obtain subsequent geo-referencing and prediction.

\section{RESULTS}

The main contribution of this methodology was a set of ten social indicators characterized in three dimensions: sociodemographic, socioeconomic, and sociocultural.

The sociodemographic dimension comprised the following descriptors: age, education level, population density, and land use. This category will permit a better understanding of whether there is any relationship between its descriptors and solid waste accumulation such as how relevant education level or age is to these processes. On the other hand, the socioeconomic dimension comprised the following descriptors: consumption patterns, the existence of ambulatory trading, and average monthly income. This layer of information provides an understanding of the economic profile of the study sector and its relationship with solid waste accumulation. For example, if the consumption pattern occurs daily rather than weekly, it could be that the generation of solid waste is greater. Finally, the sociocultural dimension comprised the following descriptors: local custom, awareness of solid waste management policies, and participation in training. This last level of information permits a better understanding of the social constructs in the sector analyzed. For example, it will describe residents' behavior patterns and incentives to take the garbage out (waiting for the collector or leaving it in a place that serves as an accumulation spot).

The ten descriptors mentioned above provide an understanding of the population in action, thereby helping to protect their environment by identifying whether there is a lack of opportunity for development to improve residents' living conditions. To understand the importance of the proposed indicators, official information provided by the INEI during the last 2017 census was used because it collected multiple social indicators to assess inhabitants living conditions. Statistics for the study area indicated that $82 \%$ of dwellings were inhabited. Another important fact is that $71.3 \%$ of dwellings have both basic water and electricity 


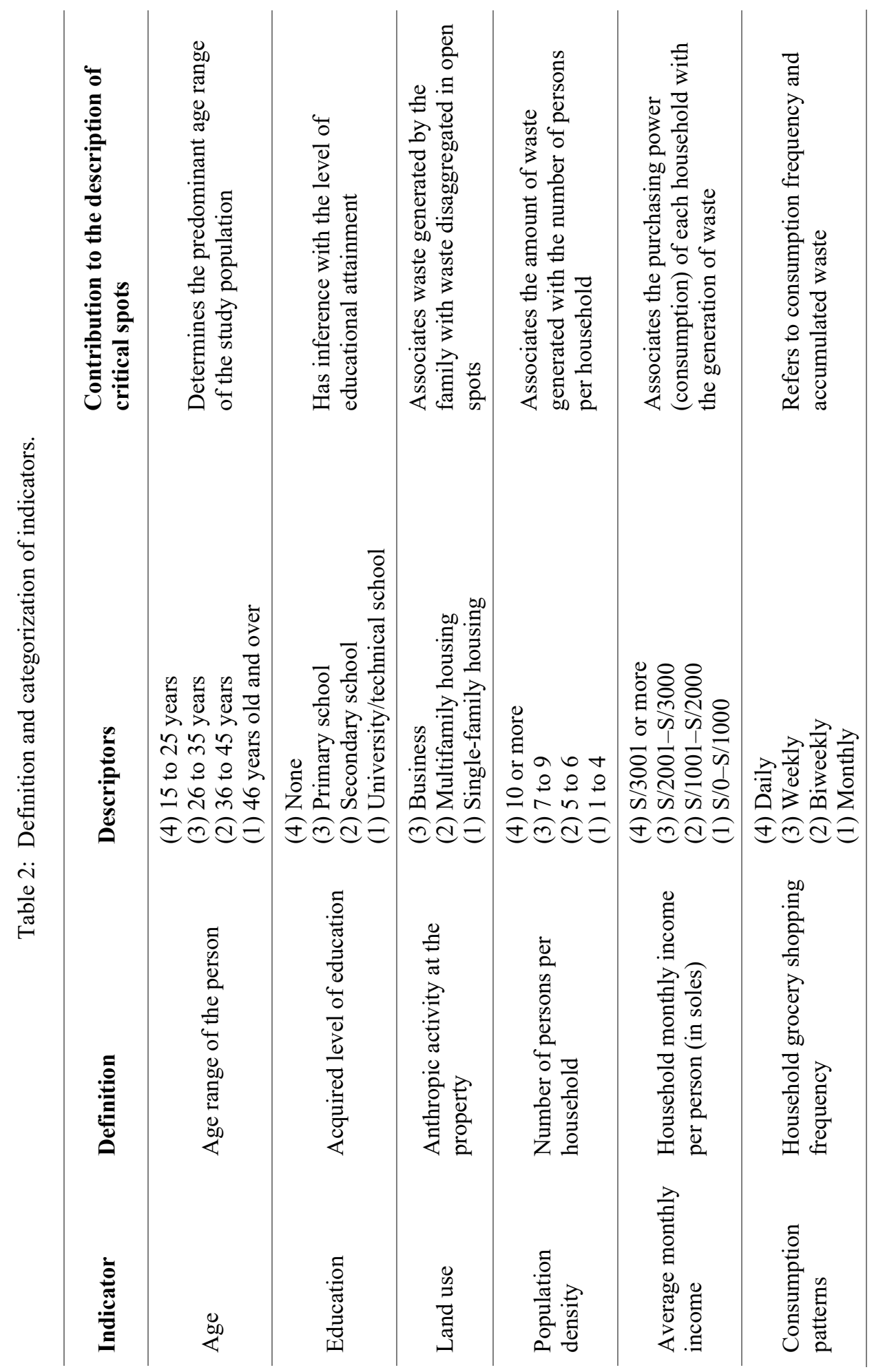




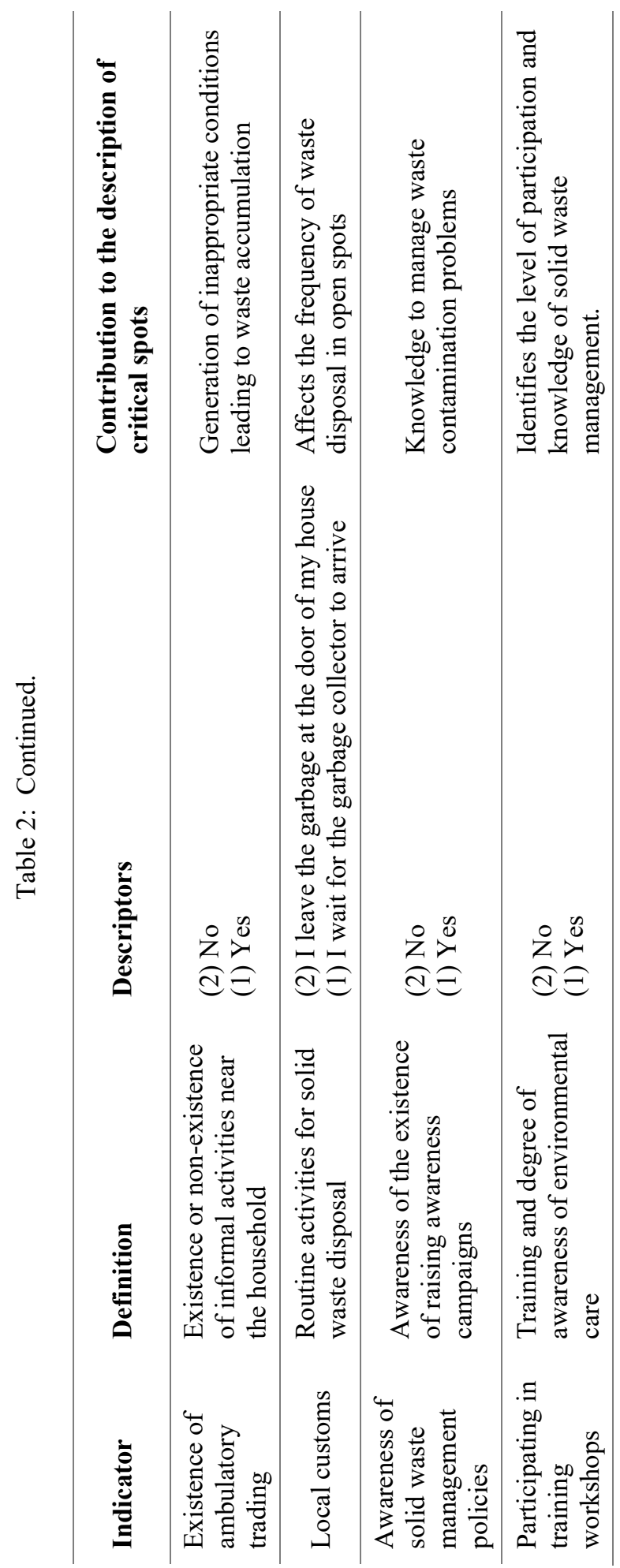


services. In terms of educational level, $44.4 \%$ of the population had completed secondary school and 4\% never had an education. Age stratification measures indicated that $46.6 \%$ of the residents were between 18-44 years old. Economic profiling indicated that $34.35 \%$ were independent workers, $32.07 \%$ were employees and $23.84 \%$ were engaged in mixed activities. Finally, the family composition tended in most cases to consist of 4 people (70.02\%) [28].

\section{DISCUSSION}

The proposed set of indicators provides a robust and replicable tool to identify places prone to solid waste accumulation. In addition, it could contribute to the optimization of municipal management, providing methods that make it possible to understand residents better and implement a management plan according to their needs. It is important to understand the attitudes and beliefs of a population to understand how individual behavior impacts on environmental contamination [29]. Therefore, social indicators help identify the behavior that generates solid waste accumulation spots, to better understand this phenomenon and implement corrective measures to improve waste treatment leading to an overall reduction in waste dumping.

Solid waste accumulation areas are difficult to predict using a single social descriptor; therefore, it was necessary to combine different descriptors grouped into the categories that we have addressed: sociodemographic, socioeconomic, and sociocultural factors. Given that it was important for the authors to prioritize indicators in order of the relevance to their respective categories, we produced a hierarchical weighting matrix based on Saaty's studies [30]. Table 3 presents the results of the hierarchical analysis.

Table 3: Hierarchical analysis of social indicators.

\begin{tabular}{|c|c|}
\hline Categories & Social indicators \\
\hline \multirow{4}{*}{$\begin{array}{l}\text { Sociodemographic } \\
\text { conditions }(\mathbf{4 8 \%})\end{array}$} & Age $(6.6 \%)$ \\
\hline & Education level $(42.2 \%)$ \\
\hline & Population density (38.1\%) \\
\hline & Land use $(13.1 \%)$ \\
\hline \multirow{3}{*}{$\begin{array}{l}\text { Socioeconomic conditions } \\
(\mathbf{1 1 . 5 \% )}\end{array}$} & Consumption pattern $(40.5 \%)$ \\
\hline & Existence of ambulatory trading $(11.5 \%)$ \\
\hline & Average monthly income $(48 \%)$ \\
\hline \multirow{3}{*}{$\begin{array}{l}\text { Sociocultural conditions } \\
(40.5 \%)\end{array}$} & Local customs $(55.7 \%)$ \\
\hline & Waste management awareness $(32 \%)$ \\
\hline & Participation in training $(12.3 \%)$ \\
\hline
\end{tabular}

When evaluating the relevance of each category, we observed that sociodemographic and sociocultural indicators were the most relevant with $88.5 \%$ since local residents' customary disposal of solid waste depends on these. However, sociodemographic indicators including education level, closely followed by population density, and the number of household occupants directly affects the generation of waste. In the area chosen, age was not relevant, since the vast majority of the population were young [28]. In the same way, at the sociocultural level, local customs were a more relevant indicator than awareness and participation in issues related to solid waste management. This organizational hierarchy indicates that social constructs are inherent in the formation of individual behavior. Finally, socioeconomic indicators revealed that the average monthly income and consumption patterns go hand in hand. 


\section{CONCLUSIONS}

This research identified a set of social indicators that influence solid waste accumulation in urban areas. Three categories of socioeconomic, sociocultural, and sociodemographic factors were used to bundle the proposed set of indicators. Sociodemographic indicators describe the resident's social profile: land use, age, population density, and education. Socioeconomic indicators describe the relevant economic parameters influencing the accumulation process: average monthly income, consumption patterns, and the presence of ambulatory trading. Meanwhile, sociocultural indicators describe residents' awareness and subsequent behavior. Finally, this research is presented as a starting point for future research papers which will implement and validate the descriptors analyzed in this proposal.

\section{ACKNOWLEDGEMENTS}

This project was funded by Universidad Tecnológica del Perú (UTP), within the framework of the "Research Projects I+D+i 2019" agreement. The authors would like to thank Yuriko Saito and Ramzy Kahhat for their valuable comments on the previous version of this manuscript.

\section{REFERENCES}

[1] Hoornweg, D. \& Bhada-Tata, P., What a waste: A global review of solid waste management. Urban Development Series Knowledge Papers, Washington, 2012. https://openknowledge.worldbank.org/handle/10986/17388.

[2] Kaza, S., Yao, L., Bhada-Tata, P. \& Van Woerden, F., What a waste 2.0: A global snapshot of solid waste management to 2050. Urban Development Series, Washington, 2018. http://hdl.handle.net/10986/30317.

[3] Wang, L., Yan, D., Xiong, Y. \& Zhou, L., A review of the challenges and application of public-private partnership model in Chinese garbage disposal industry. J. Clean. Prod., 230, pp. 219-229, 2019.

www.sciencedirect.com/science/article/pii/S0959652619315446.

[4] PNUMA, Developing an integrated solid waste management plan: training manual. Kusatsu: UNEP, 25 pp., 2009. www.pseau.org/outils/ouvrages/ietc_developing _integrated_solid_waste_management_plan_training_manual_vol_2_assessment_of_ current_waste_management_system_and_gaps_therein_2009.pdf.

[5] Espinoza, C., Management of domestic and non-domestic solid waste in the municipal management of the city of Huancavelica, period 2016. Repositorio Institucional (UNH), Universidad Nacional de Huancavelica, 2018.

http://repositorio.unh.edu.pe/handle/UNH/1830.

[6] Salazar de la Rosa, N., Solid waste management in food companies. Universidad Nacional Agraria La Molina, 2018.

http://repositorio.lamolina.edu.pe/handle/UNALM/3586.

[7] MINAM, Legislative Decree No. 1278. R.M.N 024-2017-VIVIENDA Perú, 35 pp., 2017.

[8] INEI, Peru: Environmental Statistics Yearbook 2014, Lima, 574 pp., 2015. www.inei.gob.pe/media/MenuRecursivo/publicaciones_digitales/Est/Lib1197/ libro.pdf.

[9] MINAM, National plan for the comprehensive management of solid waste 2016-2024. SINIA: Perú, p. 85, 2016. https://sinia.minam.gob.pe/documentos/plan-nacionalgestion-integral-residuos-solidos-2016-2024. 
[10] OEFA, Environmental monitoring of solid waste from provincial municipal management. SINIA: Lima, 2014. https://sinia.minam.gob.pe/documentos/ fiscalizacion-ambiental-residuos-solidos-gestion-municipal-provincial.

[11] Cárdenas, G., The city and the garbage. RPP, 2018. https://rpp.pe/lima/actualidad/laciudad-y-la-basura-lima-retrocede-en-la-lucha-por-controlar-sus-residuos-solidosnoticia-1114285.

[12] Alata, P., Sustainable country, GRUPO RPP: Lima, 2019.

[13] Lima Cómo Vamos, IX Perception report on quality of life in Lima and Callao. Encuesta Lima como vamos, Lima, 2018. www.limacomovamos.org/cm/wp-content/ uploads/2018/12/EncuestaLimaComoVamos2018.pdf.

[14] Klinger, R., Olaya, J., Marmolejo, L. \& Madera, C., Sampling plan for the quantification of residential solid waste generated in urban areas of intermediate size cities. Rev. Fac. Ing. Univ. Antioquia., 48, pp. 76-86, 2009. www.scielo.org.co/ scielo.php?script $=$ sci_abstract\&pid=S0120-62302009000200008\&lng=e\&nrm= iso\&tlng=e.

[15] Pakpour, A.H., Zeidi, I.M., Emamjomeh, M.M., Asefzadeh, S. \& Pearson, H., Household waste behaviors among a community sample in Iran: An application of the theory of planned behavior. Waste Manag., 34(6), pp. 986-986, 2013. https://linkinghub.elsevier.com/retrieve/pii/S0956053X1300514X.

[16] Kannangara, M., Dua, R., Ahmadi, L. \& Bensebaa, F., Modeling and prediction of regional municipal solid waste generation and diversion in Canada using machine learning approaches. Waste Manag., 74, pp. 3-15, 2018.

[17] Torres, A., Garnica, J. \& Niccolas, H., Methodology to generate a comprehensive solid waste management model. Pachuca case study. XV International Congress of Research in Administrative Sciences, 2011.

[18] Van Dooren, C., Janmaat, O., Snoek, J. \& Schrijnen, M., Measuring food waste in Dutch households: A synthesis of three studies. Waste Manag., 94, pp. 153-164, 2019.

[19] Suthar, S. \& Singh, P., Household solid waste generation and composition in different family size and socioeconomic groups: A case study. Sustain. Cities Soc., 14(1), pp. 56-63, 2015. www.sciencedirect.com/science/article/abs/pii/S2210670714000821.

[20] Philippe, F. \& Culot, M., Household solid waste generation and characteristics in Cape Haitian city, Republic of Haiti. Resour. Conserv. Recycl., 54(2), pp. 73-78, 2009. www.sciencedirect.com/science/article/abs/pii/S0921344909001359.

[21] Torres, A., Del Castillo, A., Mezones, J., Yong, J. \& Revichagua, C., Statistical Compendium Lima Province 2018. www.inei.gob.pe/media/MenuRecursivo/ publicaciones_digitales/Est/Lib1655/libro.pdf.

[22] MINAM, Ministry of Environment identifies 92 districts that need to take action to improve solid waste management, 2018. www.minam.gob.pe/notas-deprensa/ministerio-del-ambiente-identifica-92-distritos-en-situacion-de-riesgo-pormanejo-de-residuos-solidos/.

[23] Acuña, S. \& Valera, V., Indicators of waste generation and solid waste in Venezuela. Redisa, 1, pp. 1-11, 2008.

[24] Izquierdo-Horna, L. \& Kahhat, R., Methodological framework to integrate social and physical vulnerability in the prevention of seismic risk. WIT Transactions on Engineering Sciences, vol. 121, WIT Press: Southampton and Boston, pp. 69-79, 2018. 
[25] Ibañez Forés, V., Bovea, M.D. \& Coutinho-Nóbrega, C., Proposal of social indicators to assess the social performance of waste management systems in developing countries: A brazilian case study. Perspectives on Social LCA: Contributions from the 6th International Conference, Paraíba, pp. 95-103, 2020. www.researchgate.net/ publication/335612756_Proposal_of_Social_Indicators_to_Assess_the_Social_ Performance_of_Waste_Management_Systems_in_Developing_Countries_A_ Brazilian_Case_Study.

[26] Durán, $\bar{C}$., Spatial analysis of social, economic, physical and environmental vulnerability conditions in the Colombian territory. Perspect. Geográfica, 22(1), pp. 11-32, 2017. www.scielo.org.co/pdf/pgeo/v22n1/0123-3769-pgeo-22-01-00011.pdf.

[27] Thomas Bohorquez, J., Social vulnerability assessment of natural hazards in Manzanillo (Colima). A methodological contribution. Investig. Geogr., 81(100), pp. 79-93, 2012.

www.scielo.org.mx/scielo.php?script=sci_arttext\&pid=S0188-46112013000200007.

[28] INEI, National Census 2017: XII of population,VII of housing and III of indigenous communities, 2017. https://censos2017.inei.gob.pe/redatam/.

[29] Brown, D.P., Garbage: How population, landmass, and development interact with culture in the production of waste. Resour. Conserv. Recycl., 98, pp. 41-54, 2015. www.sciencedirect.com/science/article/pii/S0921344915000440.

[30] Saaty, T., The Analytic Hierarchy Process, New York: McGraw-Hill, 1980. 